\title{
Gothic "Voodoo" in Africa and Haiti
}

\section{Eric Montgomery}

\author{
Michigan State University, United States of America
}

\begin{abstract}
This paper seeks to historicize and demystify "Voodoo" religion in Africa and Haiti while also drawing comparisons and contrasts to concepts and themes related to "the gothic". What is assumed to be "supernatural" or "paranormal" in Western and Gothic circles has long been a part of everyday reality for many peoples of African descent and devotees of Vodun in Western Africa and Vodou in Haiti. Tropes that are essential to realms of the gothic (supernatural characters, mystery, the macabre, spirits, and paranormal entities) - are also central to the cosmology and liturgy of so-called "Voodoo". As "the gothic" undergoes a resurgence in academic and popular cultures, so too does "Voodoo" religion. And yet, both terms continue to be conflated by popular culture, and by equating "voodoo" with "the gothic", the true spirt of both concepts become confounded. A certain racialized Eurocentric hegemony devalues one of the world's least understood religions ("Voodoo") by equating it with equally distorted concepts of "the gothic". As globalization transforms society, and the neo-liberal order creates more uncertainty, the continued distortion of both terms continues. Vodun does more than just speak to the unknown, it is an ancient organizing principle and way of life for millions of followers. Vodou/Vodun are not cognates of the "American Zombie gothic", but rather, are a mode of survival and offer a way of seeing and being in an unpredictable world.
\end{abstract}

Keywords: Voodoo, Vodun, Gothic, Neoliberalism, Africa, Haiti 


\section{Introduction: Gothic "Voodoo"1}

Ithough the term "Gothic" originates from the ornate architecture created by
Scandinavian and Germanic tribes called "Goths" between the $12^{\text {th }}$ and $16^{\text {th }}$
centuries, the term quickly evolved into a thematic framework for psychological and bodily sceneries for art and culture writ large. Like the term "medieval" the very mention of the term gothic conjures images of the macabre, mystery, superstition, and ghastly beings and ideas. The term has also been western-centric in that it is almost always applied to American and European peoples, to the point that in contemporary times people of color (especially black people) have felt ostracized and marginalized by "Goth Culture." When gothic narratives are applied to people of African descent, it has mostly been through negative stereotypes and unfair archetypes associated with African and Diasporic religions and rituals such as "Voodoo." Voodoo (Vodun/Vodou) and related religions like Santeria, Orisha, Macumba, Obeah, and the like, have been further demonized and equated with blood-lust, witchcraft, black magic, sorcery, and even cannibalism, to the point that they had to go underground. Only recently have they made a comeback as those in power - from Africa to Brazil, Cuba and Haiti to the United States-have begun to accept and even be initiated into these various African-based religious orders (Matory, 2018, p. 1-11; Brown, 2011). Another Eurocentric bend has been the propensity to malign African religious systems in a manner draped in racism, turning these beliefs into the "savage other", while also appropriating these frames for mass consumption. This "Halloweenification" of Vodun, Vodou, Orisha, and related orders began in colonialism and has been exacerbated in modernity where the neoliberal order turns publicity into a substitute for democracy by way of co-opted images of the "other" (Berger, 1972).

This paper seeks to historicize and demystify this ongoing discrimination by prodding the gothic trope as it relates to "Voodoo" in both Haiti and Africa. Just as the engines of popular culture and consumption have hijacked the core meanings of the term "gothic", they have also misunderstood Vodou and Vodun. This hegemony cuts deep, yielding unjustified oppression from above in places like Haiti where poverty is explained as a

\footnotetext{
1 "Voodoo" is obviously a problematic word, but for the purposes here I will use it for several reasons. First, more people will read this article, and it is the non-specialists who will benefit most from learning of the negative associations and stereotypes tied to this term. Second, I am speaking of a macro-level "Voodoo" which includes the Vodun of Benin, Vodu of Togo, Vodou of Haiti, and even the "Hoodoo" of New Orleans and some US cities. Third, I want to start a dialogue about taking back the power of the term "voodoo" by demystifying misguided and coopted connotations of the word in hopes of projecting a more accurate and benign understanding of what it means.
} 
result of "diabolical Vodou"; it garbles the intimate ties between "race" and class, and colonial and neoliberal domination by the West (see Cleophat in Montgomery, 2019; Giafferi-Dombre in Montgomery, 2019). For Haitian anthropologist Nixon Cleophat, "Vodou is the embryo and marker of Haitian socio-political identity" (Montgomery, 2019, p.59). The concerted and collective effort by outsiders to conflate "voodoo" as only "supernatural" or "paranormal" - instead of framing it through cultural relativism for what it is, a "way of life" - not only misrepresents reality, but invokes a feeling of "last-place anxiety", relegating Vodun/Vodou to the lower echelons of religious thought, and their followers to the level of barbarism (Matory, 2015). The transformative and dynamic nature of "Voodoo" religion is missed. Whereas Vodun is open-ended, unfinished, and a holistic way of being and seeing in real life, the media and popular culture of the West turns it into something less than human (Montgomery, 2016; Rush, 2013). This is despite the fact that this religion has been a part of everyday reality for many folks of African descent where the veil between past/present, life/death, and mortal/god has always been thin and easily traversed through ritual, spirit possession, and divination (Montgomery \& Vannier, 2017, p. 155; Vannier \& Montgomery, 2016, p. 107).

Gothic literature and fiction became all the rage from the late $18^{\text {th }}$ century up to the present. The odus and patakines of Yoruba Ifa divination, the mythologies of Vodun and Vodou gods, the acts of spirit possession and revelation, the articulations of plant medicine for healing - all operate in the realm of "mystery", but they are also scientific; albeit, not understood by Western empiricism or the so-called scientific method (Vannier \& Montgomery, 2016, pp. 31-38). Eurocentric bias leads outsiders with little real understanding of "Vodu" to align it with tropes from misconceived Gothic literature so ideas such as blood-sucking witches, resurrected spirits, night-flying women, shapeshifters, and a laundry list of "fantasy-like" characters including fairies, elves, tykes, giants, vampires and werewolves, garner the headlines; while the liturgical, medical, and philosophical aspects become obscured. The popular obsession with the gothic makes it a convenient medium through which to delegitimize African beliefs. As gothic fiction has become desirable and interesting (Hogle, 2002), few have been willing to include Africanity into its formal frame; even the rising numbers of Muslims and Christians in Africa obfuscates the fact that such "conversions" are filtered through an African religious imagination for which African "Traditional" Religion is the bedrock (Orabator, 2018). Perhaps the intrinsic secretive nature of Vodun has exacerbated the inability of Westerners and outsiders to understand it from the inside, instead opting to conjoin it with notions of some preconceived fictive gothic trope (Landry, 2018). The atmosphere of mystery and the unknown; the evil capacities of human and godlike agents; paranormal beings and events that stretch beyond nature; the wild and out of control propensity of 
melodramatic forces and events; omens, magical objects, visions and dreams; and, sacred settings and ceremonies-are only a small part of what "voodoo" is, yet it is only this master narrative that most of the world knows. What is missing? Well, ritual acts are also practical, servicing the sick and indigent, and also improving the lot of their devotees and adepts. These are not religions of "horror," but rather, African belief systems are pierced with balanced elements of good and evil; and through sacrifice, prayer, performance, and the like, Africans can bring order to a world full of conflict and chaos (called maso-maso in the Ewe language of Ghana, Togo, and Benin).

Many modern readers and some critics - encouraged by popular culture - have begun to think of "Gothic literature" as referring to any story that uses an elaborate setting, combined with supernatural or super-evil forces against an innocent protagonist. Some members of popular culture have continually superimposed this story arc onto African religions like "voodoo", equating it with gothic fiction, and thus doing great harm to one of the world's most ancient and important belief systems.

\section{Converting the Converter: "Goth" in African Religions}

There is little doubt that the new financial architecture of neoliberalism and global capitalism has disproportionately affected citizens of peripheral nations, particularly people of color in the Global South, and especially "black" people who continue to observe their ancestral religions, and even some whom have converted to "world religions" while also admiring the traditions of their ancestors (Soederberg, 2004). In Haiti, most followers of Vodou will pronounce themselves Catholic to avoid persecution from the inside and outside, and the same holds true in places such as Puerto Rico, Brazil, Cuba, Benin, Togo and Nigeria. Because of poverty, many adepts of Vodou in Haiti, and Vodun in Togo and Benin, flock to Christianity as a means of escaping their plight - while still adhering to aspects of their ancestral religions (Orobator, 2018; Kohnert, 2006). The interlocutors I have met during my ethnographic research on African-based religions throughout West Africa, Latin America, and the Caribbean, have learned to appear Christian, while maintaining ancestral beliefs. This leads to outsiders believing that syncretism and "conversion" has gone on, when really the supposed "converted", have instead converted the "converter". This fluidity of code-switching becomes what James Scott would call a "weapon of the weak", as a result of "spiritual insecurity" perpetuated by Western hegemony (2008; see also Falen, 2016).

While many throughout Africa and the Diaspora are forced to conceal their adherence to African Religion, it remains a repository and "the soil in which Christianity and Islam have 
taken root" (Orobator, 2018, p.77-102). Even in academic cycles, the very mention that I am an initiate and/or researcher of "Voodoo" elicits immediate cause for alarm and subtle discrimination. I am also guilty of this preconception, for the first "voodoo" ceremonies I witnessed in my teens scared me to the core as I too associated the spirit possessions and animal sacrifices with some sort of pact with the devil - and my own misguided associations of the dark tones of gothic fiction.

The gothic movement, as well as voodoo religion, are not simply en vogue lifestyles, or themes for Hollywood films; both have been shaped by neoliberal globalization, and subjected to its vampirism (Shaviro, 2002; Comaroff \& Comaroff, 2001). As the gothic undergoes a resurgence in Western popular culture, many of its ideas also proliferate in Africa and throughout the Atlantic world, for similar reasons. There is a certain resistance to the "capitalistic monsters" in both voodoo and aspects of the gothic (Langman, 2008). Fears associated with globalization in a time/space compressed world, such as growing inequality, environmental uncertainty, and post-truth, are driving tropes of the "gothic" and similar ideas also reverberate in the African Diaspora. In the tropics of the Global South, African religions are growing, not just among blacks; whites are also flocking to houses of Candomblé in Brazil, shrines of Orisha in Cuba and Puerto Rico, and also to American city-centers in search of alternatives to the "master narratives" of the so-called world religions (Olupona \& Rey, 2008). As many people feel isolated and estranged from themselves and their histories, there is a marked turn inwards toward the ancestral traditions and beliefs of mother Africa, and the supposed "tribal traditions" of Europe as well.

In contemporary African Diaspora countries there has been an escalation in reports of vampires, werewolves, and child snatchers - the dubious nature of globalization, adhering to story-lines implicit in the revival of gothic fiction (Steiger, 2010). In Haiti, this has manifested in concepts like the lougarou (werewolves) which are believed to account for the numerous missing children and the use of their bodies and parts in money-making rituals, magical implements, and blood - vital to empowering and enriching their captors. The number of these incidents has increased since 2010 with the chronic desperation that came from the environmental pressures of the devastating Haitian earthquake. In an article on the BBC (2017), they note similar events in Malawi and Brazil due to extreme poverty, and the desire for the wealthy to improve their lot by way of the blood and body parts of poor and vulnerable children. With 40 million slaves in the world today, a 
burgeoning illegal organ trade, and exponential growth of drug addiction and trafficking, these trends should shock us into acute awareness of social problems. ${ }^{2}$

In northern Ghana, among the Nankani peoples, Denham has discussed the advent of "spirit children" who manifest themselves by way of disabled or unordinary children, these "bush" spirits are believed to have supernatural powers and work to take over the home. So serious are their dangers that infanticide is present (Lancy, 2017, p. 215). These incidents read like a piece of gothic literature, but are instead manifested in real society and culture, the fantasy of books playing out in real-time and in real life. In fact, throughout Sub-Saharan Africa and the Atlantic world, the spirits of wild bush animals are believed to be able to plunge into the bodies of unborn children and pierce the very personhood and corporeality of the young. Just as human beings can shape-shift into animals, the spirits of animals can also inhabit the living. This reciprocal duality can have both positive magical and negative spiritual connotations. The negative connotations and semantics often parallel gothic archetypes such as "witches," "werewolves," and "vampires." These "muti" of Malawi, and other similar criminals preying on the weak, normalize societal fear by killing and sucking the blood of children in the name of reversing cycles of bad luck, financial woes, and infertility.

Just as Darwin's theory of evolution spiked fear in Christians regarding their beliefs in the late $19^{\text {th }}$ century, the cold realities of the post-modern transgressions and protracted structural and real violence are shattering previous class-conditioned moral frameworks and leading to what Terrence McKenna called an "archaic revival" (1991). The onslaught of the medieval, the zombies, the vampires, and also the pivot toward African religions (often because of mystification and lack of understanding) are indicative of contemporary issues regarding social, economic, and environmental justice. The same escape that Hollywood provides via the image, Vodu(n) and Orisha seem to offer through alternative ways of knowing, at least to many new Western converts - a fetishism of attraction to the "gods that black people make" (Matory, 2018). The mimetic desire for the other, especially the uncanny, sublime, and supernatural, is assumed to be a characteristically modern one, where "strange places" and marginal ideas flourish. But this desire to copy the sublime has always been part of African and European philosophies. When initiated into Vodun or Orisha, folks go someplace other, namely the sacred forest (Zogbe in Ewe). When the gods choose their spirit "wives" (vodunsi) in what is called an "opening of the mouth ceremony", it is often threatening or violent, sometimes sexually enticing, and

\footnotetext{
${ }^{2}$ For an example of the global reach of this idea of organ harvesting, neoliberalism, mythology and contemporary culture see Joyce (2018) who discusses these ideas in the region of Southeast Asia.
} 
always mysterious, distant, and enchanted (certainly gothic tropes!). The ideas of Gorovodu in Togo, Yewe Vodun in Benin, and Vodou in Haiti, mesh with Freud's notion of the "uncanny" or "that class of the frightening which leads back to what is known of the old and long familiar" (Freud \& McLintock 2003; see also Rosenthal, 1998, p. 195-233). The gothic novel and the Vodun/Orisha rituals are simultaneously frightening and strangely familiar, with episodes of delightful ecstasy and transformation. Such ecstasy/transformation is evident in the possession episodes I have witnessed or experienced in southern Togo.

When the slave spirits of Mama Tchamba visited me in a shrine in Togo in 2014, I was overcome with sadness and drenched in tears, the ghosts of the slaves, and phantoms of my own slave-owner ancestors, erupted within my corporeal being, leaving me deranged, and plunging me into the ecstasy and perils of possession trance (Montgomery, 2018, pp. 25-40). These slave spirits are often referred to as vumeku (those who died in blood), and since they died a violent death, they too are uncanny, and demand attention. If disrespected, they return to negatively affect the living descendants, especially Africans (and Americans), of those who helped to enslave them - demanding reconciliation, sacrifice, libations, and the chance to come back and dance the bodies of their former slave owners. Many of these northern slaves married into Ewe patrilineages and constitute a part of who these living persons are today. The ghosts of the past are dispossessed, bringing with them a demand, a curse, a plea, and an ability to transcend time, place, and personhood. One's very identity intersects with these spirits of the past, and appeasing them is a moral mandate, which, if left unfulfilled, can inflict great harm on the living.

Both "Voodoo" and the gothic speak to pervasive violence and differences in power. The stories from gothic literature, like the myths and rituals of "Voodoo", are full of constraint, then release, and physical and psychological suspense that something is about to happen. Gothic literature is filled with "cursed" and maligned women who (like spirit-wives in trance) break rules, norms, and taboos at will. The same sexual difference and great ambiguity at the heart of the gothic is also central to the spirit possessions of Vodun adepts - driven by resistance to power, questions of sexual identity and desire, pleasure (jouissance), and transformation (Rosenthal,1998, p. 197). While in trance, the vodunsi can overtake the power of the priest, or the chief, sometimes calling them out for transgressions they have committed against the community. In 2015, while in Ouidah, Benin, I saw a "wife" of the thunder god Heviesso call out the head-priest for sleeping with younger girls in the village and using sacred medicines (atike) to steal their innocence. This priest (Sofo, Hounsi) was later judged by a group of other priests and stripped of his 
powers. He moved to Togo with one of his sons and never again assumed the duties of the shrine.

\section{Terror, Horror and Pleasure in Gothic Vodun}

It is interesting that when readers and viewers of gothic literature and film take pleasure in horror and macabre events that it is most often considered "taste" or sometimes artistic preference. And yet when outsiders witness, often without context, what they believe to be "dark forces" in Vodun or other African rituals, they normally consider them to be "primitive," "savage," "diabolical," and "ungodlike." When French and British audiences first witnessed the pioneering cinema verité of Jean Claude Rouch in his ethnographic films Les Maitres Fous (1955) and Jaguar (1967), these rites were not looked upon as expanding the soul or with cultural relativity, but were instead deemed barbarous and savage (Rouch, 2003). Rouch's work 70 years ago in Sub-Saharan Africa challenged orthodoxy by allowing subalterns a voice and agency in the afflictions of colonial hegemony. However, the sacrifice and eating of the dog and the foaming at the mouth in his film Les Maitres Fous were not viewed as high art, but instead relegated to the label of "savage horror." In contrast, the horror and terror of a Bram Stoker or a Radcliffe novel is viewed as "high art," a psychological thriller of contrasts and mental expansion. Today many cultural theorists and critics see Rouch in the same light; yet, his "art" was simultaneously non-fiction documentary film at its best.

Although many instances of possession trance can be benign, and sometimes even blissful and loving, other times they can invoke great fear in the participants. The rolling back of the eyes, the high level vibrations and bodily contortions, the shrieking and superhuman strength can be as scary as they are awe-inspiring, mostly because unlike the gothic novel or horror film, they are not fiction, they are truthful and playing out live right before one's eyes. After witnessing spirit possession episodes on this level, the horror of gothic novels and films seem almost amateur - at least to this author. Both of these examples are mechanisms of resistance to domination in its own right. To invoke Edmund Burke (2009), the beautiful can be sublime, the sublime beautiful, and the wall between consummate fear and overwhelming ecstasy can be shattered by gothic art, and certainly by Vodun ritual and performance. They both give us the experience of the sublime, filling our everyday life with alternative ways of seeing and comprehending beyond our preexisting reason and intellect. The inexplicable can be as profound as it is life-altering. 
Michael Taussig quoting Walter Benjamin writes: "From the tradition of the oppressed, we realize that the 'state of emergency' in which we live, is not the exception, but the rule" (2018, p. 193). For most Haitians, Togolese, and Beninese adepts of Vodun and Vodou - and others of the tropics in places such as Cuba, Brazil, or Puerto Rico - life is fragile, and when the average income is under $\$ 10$ per day, then, this state of emergency is very real. In the US, until 9/11, we did not really know what "terror" was, but for most citizens of the Global South, terror and horrific violence have long been regular events - from slavery to neoliberal modernity - and the trauma which has been unleashed affects people's self-image and perception of this world. Structural violence is a form of dysfunction which prevents marginalized citizens from basic human rights such as peace, education, access to healthcare and clean water. Life under the 50-year reign of dictatorship in Togo, or in the refugee camps of modern Haiti, reeks of political instability, and leads to social unrest. These social inequalities also allow for horror and terror to invoke certain responses, especially supernatural explanations in areas where misunderstood spirituality and structural violence exist side by side. From slavery through postcolonialism, the devotees of "Voodoo" have consistently been among the most maligned people on the planet. African Vodun, Haitian Vodou, and New Orleans Voodoo have all been subjected to false interpretations for centuries, and while the rise of vampirism in pop-culture from "Twilight" (Meyer, 2009) and "True Blood" (Ball, 2008) gives many ideas for new life in a modern world, these cultural interpretations also conversely reinforce long-held beliefs about adepts of Voodoo as well.

For many of us these entities of horror and terror are irresistible, and while vampires and werewolves gain strength by sucking the life essence (blood) out of their victims, the gods of Voodoo demand the blood of their preferred animals for their devotees to thrive and survive. Ogou, god of iron, prefers sheep, Papa Kunde of Gorovodu eats dogs, while Heviesso, god of justice and thunder, desires rams. While vampires seek human blood, and Voodoo gods the blood of animals, it is all about sustaining one's vital life force as global capitalism sucks the life source out of millions with alarming impunity. Morality is founded on self-transcendence, and "the logic of sacrifice" is about restraining one's selfinterest and tendency toward violence by inflicting violence on others (see Girard, Oughourlian, \& Lefort, 2003). For vampires, original sin is extended to fellow human beings; whereas in voodoo animal sacrifice, the original sin of violence is carried out on animals as a way to "purify" human acts of violence. This logic of sacrifice can render criminals martyrs, and devotees faithful. Sacrifice gives worth to one's life by appeasing higher powers; while self-professed vampires and werewolves (albeit not gothic literature itself) justify their superhuman inhumanity as an act of carrying out society's greater good. Whereas one act is about collective transcendence (Voodoo animal sacrifice), the latter 
self-pronounced "gothers" (who drink blood) seem misguided at best, and horrific at worse. Still, for all of the susceptibility to distortion, blood-letting in both instances finds uncanny moral justification enveloped in ideas of social solidarity - both the vampire and voodoo adepts are bound together in sacralized acts of supposed transcendence. The veil between killing and living, religion and violence, and production and destruction, is brought into critical examination - and by provoking horror and terror, somehow one's beliefs in a greater good are validated. Both believe they are achieving a proper goal, and the sacrifice of an animal, or another human being, become an act of building selfassurance and social solidarity and cohesion.

\section{Witches, Werewolves and Vampires in Africa and Haiti}

The science, art, and philosophy that goes into the construction of certain "god-objects" and ritual symbols in Vodun is comprehensive. In Togo and Benin in 2014, I conducted what I called an "ethnography of the shrine", posited first on the material culture and sacred objects of the shrine, and later on supernatural creatures believed to exist among us mortals (Montgomery \& Vannier, 2017). In my notes on the analysis of supernatural creatures which was carried out with Sofo Bisi, I refer to them as his "magical toolbox" and when he spoke of the vast array of supernatural beings, other priests who were present confirmed his assertions with stories of their own. Translation from Ewe to French and back to English was difficult, but many entities were unveiled. There were tykes, giants, fairies, fireflies, werewolves, elves, chimeras, witches, tree/plant spirits, snake spirits, water spirits, and many more. One of the assistant priests drew a few of these beings, and among the most interesting perpetrators of witchcraft (Aze, Akapase) was a firefly-like entity called "Adze."

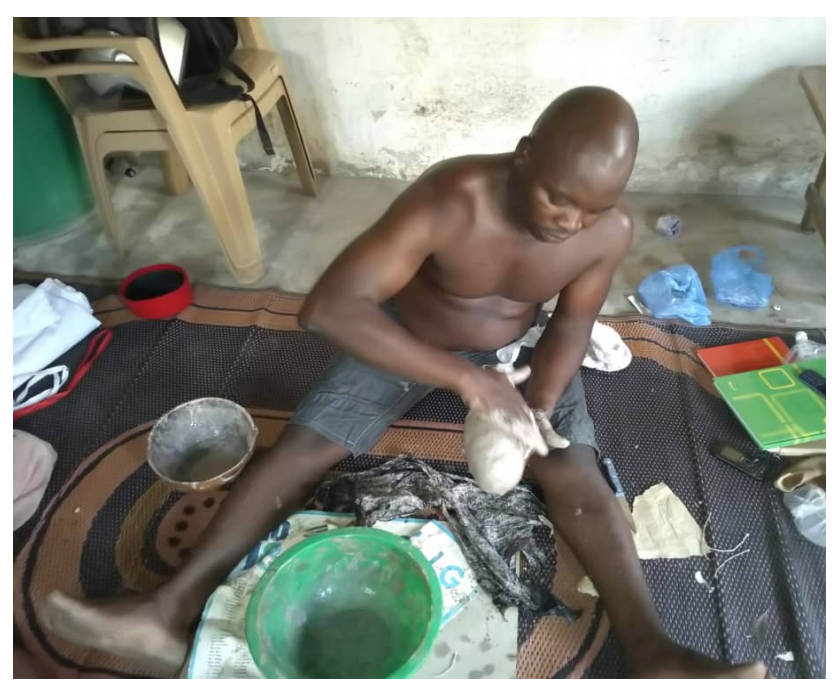

Figure 1. "Fetish Washing". The bokonosofo (priest) washes and prepares the god object with sacred plant medicine and soap, this object is part of the warrior pantheon (Bangre) of Gorovodu (Tron). February 2019, Lome, Togo. Photo by: Koffi Kodjopui Modest 
Figure 2. "Fetishes of Gorovodu". Many of the god objects of Gorovodu (Kunde, Ablewa, Sunia Kompo, Bangre). They will be placed in the shrine and consecrated with the blood of animals and necessary rituals. February 2019, Lome, Togo. Photo by: Koffi Kodjopui Modeste.

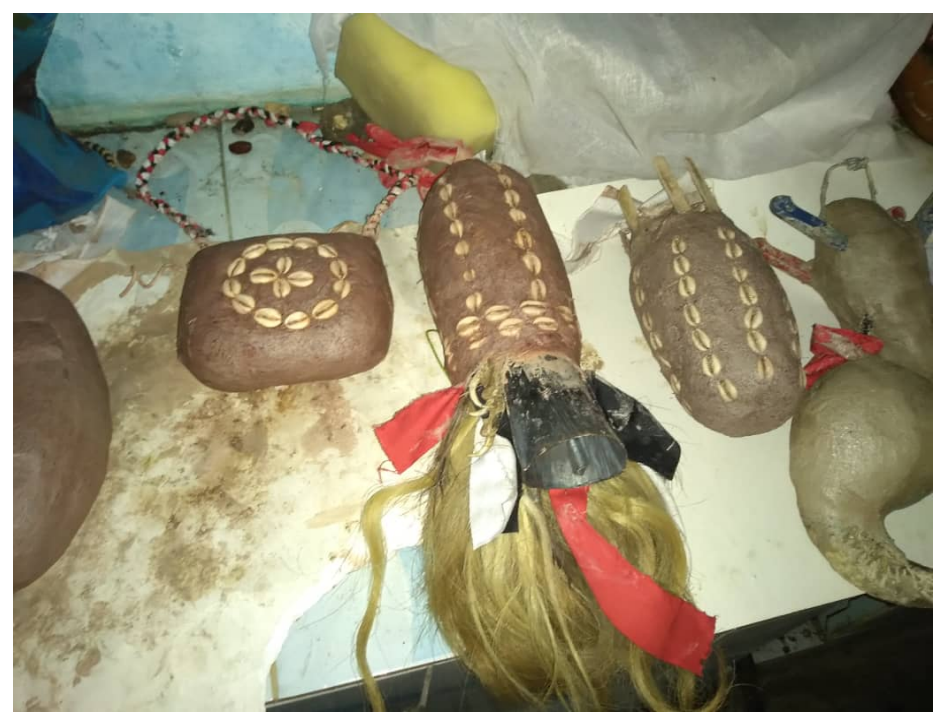

Adze are mythological, but also "seen" by everyone, to the point that many people mention them visiting in dreams, and especially in the wee-hours of the late night when heading out to sea to fish. The Adze are shapeshifting vampires and also a part of the folklore of nearby Ga-Adangbe, Mina, and Adja ethnic groups. Like the earth goddess Sakpata, the Adze originated as disease-warning entities, specifically regarding the effects of mosquitos and malaria in the region; but also hepatitis, tetanus, and tuberculosis. If captured, their powers can be controlled, but once liberated from their human shells they take the form of miniscule fireflies with ant-eater like trunks for sucking blood, and a firefly body. By concealing their identity, Adze can shimmy under doorways and crawl through keyholes, and thus approach unsuspecting victims. They feed on the blood of humans, especially children and newborns. They are indestructible; insecticides and preventative magic are deemed ineffective -they are only mortal in their human form. They are also extremely agile and very difficult to capture. According to my contact Sofo Amagbe, An Adze was caught in Eastern Tog in 2012. The captured firefly transformed back into a woman, shattering the jar in which she was imprisoned. The Adze had to be subdued. According to the story of a local priest, one such being admitted to turning into a quasi-human vulture with long talons and attacking children throughout the Bight of Benin; she self-confessed to sucking at least seven children dry and leaving their bodies in the nearby ocean. Eventually, this evil supernatural creature will become sick and die, but not before leaving serious carnage in his/her wake. Not only were infants killed, but entire lineages later fell sick, and reserves of palm oil, milk, and palm wine went missing as a result of the Adze's voracious appetite. Adzes are but one form of vampire, and there are dozens of other types in constant conflict with one another, causing bloodshed among 
human beings (Washington, 2005, p. 56-57). These stories serve as cultural responses to oppression, and there is a correlation between suffering and the frequency of such cultural narratives. These spirits are ancient, but with increased globalization and social inequality, the past thirty years has seen a resurgence in Adze activities. One priest told me it is a result of deforestation, which has left these bush flies enraged and vindictive; while another priest believed it is due to the decline of indigenous rituals and necessary pacifications as a result of the rise of Islam and evangelical Christianity.

The unfortunate folks subjected to such "gothic ordeals" can sometimes be just a matter of coincidence, but most of the time it stems from passionate envy ( $n^{\prime}$ bia) or violations of sacred social norms and Vodun law. Every kind of undead - from the ghosts of slaves, to incarnations of vampires, witches, and zombies - are part of the collective beliefs of Vodou worshippers of Haiti and adherents of Vodun in Togo and Benin. Max Marwick has discussed the prevalence of witchcraft accusations as a "social-strain gauge" meaning that witchcraft and its corollary spiritual enforcers work to keep morality and ancient customs alive (1950, p. 103). Rising social inequality, modern spikes in violence, and the breaking of age-old taboos such as drinking, stealing, and lying, are believed to increase? the frequency of supernatural activity. When rules and norms are broken, supernatural beings work to create order and discipline. In his analysis of Haitian zombies, Wade Davis explained that the dioxin from the pufferfish was the elemental component for rendering a human a zombie, but the greater spiritual reasons were to punish evil-doers and transgressors (2000). Although Marwick and Davis's "functional explanations" are rather mechanistic, they do highlight the fundamental reason for the existence of witchcraft and zombification; that is, to deter criminality and to build a greater cooperative morality.

The lougarous (werewolves or vampires) of Haiti have also experienced a revival of sorts, especially since the 2010 Haitian earthquake and due to increased social stratification indicative of present times. Derby (2010) synthesized the prominence of reports of demonic pigs, a local variant of the lougarou, along the Haitian-Dominican borderlands, and associated them with memories of violence and male heroism. "Manje" in Haitian Creole means to eat or feed another. This concept as a socio-spiritual conception in Haitian culture carries both symbolic and real significance, and when "donors" are believed to be lourgarou they are often poisoned or killed via sorcery (Stevens,1995, p. 77). The past decade has seen a pronounced intensification in lougarou accusations and incidents involving victimization. Not all perdition is believed to have been caused by spirits beyond the grave; the lougarous can take the form of a plethora of animals and are often seen keeping a "nighttime vigil" on the roof of the victim's house before attacking the unborn child in the mother's womb, and sometimes a newborn itself. Misogyny and 
discrimination is often at play here, and many women are condemned as lougarous without any supporting evidence. Patriarchal men, and others of privilege, openly discriminate against outspoken and brave women (Sarthou, 2010). The work of Edwidge Danticat details the trials and tribulations of "flying women" labelled as "lougarous" in Haiti, and most often those accused are independent and older women who live alone-easy targets for misogyny and discrimination. The mysterious werewolves and vampires of Haiti beg deeper questions, especially since such stories and accusations escalate along with parallel increases in poverty, homelessness, criminality, and desperation. Poverty also opens the doors to human trafficking and kidnappings demonstrating the desperate actions of these desperate times and evidence of a pronounced spike of "the gothic in the age of terror" (Liénard-Yeterian \& Monnet, 2015).

The werewolves of Greece (lycanthropus) and Ireland (faoladh) were also more popular during tumultuous times of social and political upheaval. Thus what we are witnessing in the Global South has universal precedence. In Trinidad, the legarou, and in Brazil, the lobizon, are also shape-shifting monsters coinciding with the blood-sucking nature of global capitalism that creates inequality everywhere it spreads. The sinister nature of neoliberalism bequeaths an equally ominous response when humans can twist and transform into animals. Just as normal humans can be altered by the love of money and its associative greed, so too can other humans turn themselves into greedy monsters feeding on the blood of children and other vulnerable persons. People are afraid, and they are desperate, and this often leads to hate and hysteria. When the 2010 earthquake in Haiti killed tens of thousands and uprooted three million people, folks began keeping a night lookout for monsters, leading to bloody retribution on a massive scale. As disaster and pain pervaded the scene, the werewolves were also running amok, the present quickly became "gothic", with increased instances of kidnapping and child smuggling, particularly in Haiti where thousands of children were left homeless or orphaned. Modern problems can open up the debate for ancient explanations, and how far-fetched is it really to blame the "lougarous", for many people are indeed profiting off the blood of real Haitians: relief agencies, churches, and foreign multinational corporations. Of course, most of these kidnappings are carried out by roving local gangs looking to sell the children into slavery for a profit, but foreigners are also complicit, sometimes in an effort to take them away for legal and illegal adoption in what they believe to be a better world. One case involved the arrest of ten American Baptist aid workers who were accused of attempting to smuggle across the border 33 homeless children ranging from twelve months to twelve years old. As for child stealing as it relates to werewolves, the upsurge in reports of the "je-rouges" or "lougarou" of folklore after the earthquake stems from a volatile combination of the increased vulnerability of populations affected by the disaster, 
the devious nature of human thugs who prey on the weak, and the increased reliance on the belief in mysticism and Vodou to cope with the fierce poverty many are forced to endure.

As anthropologists we are not in the business of absolute truth, we leave that to the philosophers. And people in West Africa, Latin America, the Caribbean, or the tropical Global South more widely, adamantly insist that there are supernatural creatures (Adze, Lougarou, Chupacabra, etc.). Meanwhile, many subcultures of the West opt to consume wide-ranging aspects of gothic entertainment for much the same reasons. As modernity and neoliberalism continues to leave masses of people excluded -the darkness that has descended becomes not only that of disaster and human suffering, but also of frightening supernatural disorder complete with accompanying monsters. In some cultures, stories and characters considered legendary, and what we consider to be myth, become intimately connected to the realities of life. Furthermore, in Western cultures these beliefs and ideas are also growing, in both our imaginations and our collective imaginations.

\section{Conclusion}

African religions are rarely granted the respect and attention they deserve and have long been excluded from the status and prestige relegated to other religions. Instead they are associated with the zombies and witches of popular culture, and thus misappropriated as gothic. Gothic revival, and renewed interest in African religions, constitute two sides of the same coin - a desire to respond to and resist the inequality and social injustice of the world. Nevertheless, in this paper I do not intend to romanticize or incorrectly frame aspects of Voodoo by equating this truly global religion with vampirism or even modern gothic culture. Voodoo, like most religions of the world, is an age-old belief system informed by morality and empowerment, and the gothic refers to a time in history, style of architecture, or "finding beauty in the dark side"; both are also lifestyles and subcultures that continue to grab the imaginations of people throughout the world. This in itself is uncanny and sublime, and yet the fact that both ideas are so prevalent in the postmodern world and often conflated with one another, speaks to the amount of misinformation and misunderstanding of both ideas: Voodoo and The Gothic.

When several years ago "American Horror Story: Coven" (see Keetley, 2013) pivoted around New Orleans' "Voodoo Priestess" Marie Laveau, I was at first highly critical. However, upon deeper reflection, I realized that the series actually did as much to clarify Voodoo as it did to mystify it. For the participants of Vodun and Vodou rituals, "voodoo" spirits are the center of religious life: an open-ended, dynamic, and divine way of seeing 
and being, of healing, performance, and moral code, worshipped by millions of people in Western Africa and throughout the Atlantic world. Contrary to popular belief, Voodoo is not about pins and needles, and curses (Bo), but about devotion to the ancestors and a belief in an almighty god (Mawu or Bondye). Nevertheless, it is still too often associated with European witchcraft. Unfortunately, these grave misunderstandings and conflations, forged by centuries of racism and colonialism, have become the popular narrative. Regrettably, we anthropologists have failed to bring to Vodun/Vodou the collective respect and research attention given to other religions like Christianity, Islam, or Buddhism.

As "the gothic" is undergoing a resurgence in academic and popular cultures, so too is "Voodoo" religion. As globalization transforms society, and the neoliberal order creates more uncertainty, tropes of both "the gothic" and "voodoo" resonate and gain momentum. There are now more "white" initiates of Vodou in Haiti and the Caribbean than ever before, and in my village in Togo, Western Africa, dozens of Europeans, Asians, and other nonAfricans have undergone initiation into Afa, Gorovodu, and Yewe Vodun. Just like the gothic, Vodun allows us to delve into the unknown, the unseen, leaving us in the state of liminality where one is between and betwixt, searching for new truths and fulfilling new desires. In the spaces and places of "Voodoo" in Haiti, Togo, and Benin, people are crossing borders and metaphysical barriers in search of something new and different. This holds not just for popular culture such as gothic film, literature, and music, but also for religious culture as it pertains to earth-based religions such as Vodun/Vodou, Santeria, Obeah, Candomblé, Orisha, and a multitude of other African Diasporic religions. In a time of exponential globalization, and growing postcolonial economic disparities, the "tropical gothic" and its many tantalizing symbols are irresistible for many, and for some, pleasures of desire. 


\section{References}

Ball, A. (Producer) (2008). True Blood. [Television series]. Los Angeles, CA: HBO

BBC, October 20, 2017, on "Malawi Cracks down on 'Vampire' Lynch Mobs" https://www.bbc.com/news/world-africa-41692944

Berger, J. (2008). Ways of seeing (Vol. 1). London, UK: Penguin.

Brown, K. M. (2011). Mama Lola: A vodou priestess in Brooklyn (Vol. 4). Oakland, CA: University of California Press.

Burke, E. (2009). A philosophical enquiry into the sublime and beautiful. London, UK: Routledge.

Comaroff, J., \& Comaroff, J. L. (Eds.). (2001). Millennial capitalism and the culture of neoliberalism. Durham, NC: Duke University Press.

Davis, W. (2000). Passage of darkness: The ethnobiology of the Haitian zombie. Chapel Hill, NC: University of North Carolina Press.

Derby, L. R. (2010). Male Heroism, Demonic Pigs, and Memories of Violence in the HaitianDominican Borderlands. escholarship.org.

Falen, D. J. (2016). Vodún, spiritual insecurity, and religious importation in Benin. Journal of Religion in Africa, 46(4), 453-483

Freud, S., \& McLintock, D. (2003). The uncanny. London, UK: Penguin.

Girard, R., Oughourlian, J-M., \& Lefort, G. (2003). Things Hidden since the Foundation of the World. London, UK: A\&C Black

Hogle, J. E. (2002). The Cambridge companion to Gothic fiction. Cambridge, UK: Cambridge University Press.

Joyce, M. J. (2018). The Vampires Our Age Deserves: $21^{\text {st }}$ Century Forms of Ancient Evil, eTropic: electronic journal of studies in the tropics 17(1), 117-136. https://doi.org/10.25120/etropic.17.1.2018.3645

Keetley, D. (2013). Stillborn: The Entropic Gothic of American Horror Story. Gothic Studies, 15(2), 89-107.

Kohnert, D. (2006). "Cultures of Innovation of the African Poor. Common Roots, Shared Traits, Joint Prospects? On the Articulation of Multiple Modernities in African Societies and Black Diasporas in Latin America." MPRA Paper. GIGA - German Institute of Global and Area Studies / Institute of African Affairs.

Lancy, D. F. (2017). Spirit Children: Illness, Poverty, and Infanticide in Northern Ghana. Denham, Aaron R. Madison, WI: University of Wisconsin Press.

Landry, T. R. (2018). Vodún: Secrecy and the Search for Divine Power. Philadelphia, PA: University of Pennsylvania Press.

Langman, L. (2008). Punk, porn and resistance: Carnivalization and the body in popular culture. Current Sociology, 56(4), 657-677.

Liénard-Yeterian, M., \& Monnet, A. S. (2015). The Gothic in an Age of Terror (ism). Gothic Studies, 17(2), 1-11.

Marwick, M. G. (1950). Another modern anti-witchcraft movement in East Central Africa. Africa, 20(2), 100-112.

Matory, J. L. (2018). The Fetish Revisited: Marx, Freud, and the Gods Black People Make. Durham, NC: Duke University Press. 
Matory, J. L. (2015). Stigma and culture: Last-place anxiety in Black America. Oakland, CA: University of Chicago Press.

McKenna, T. (1991). The archaic revival. San Francisco, CA: Harper.

Meyer, S. (2009). The twilight saga collection. New York, NY: Little, Brown Books for Young Readers.

Montgomery, E. J. (2019). "Slavery, Personhood, and Mimesis in Ewe Gorovodu and Mama Tchamba." In E.J. Montgomery (Ed.), Shackled Sentiments: Slaves, Spirits, and Memories in the African Diaspora (Chapter 4). USA: Rowman and Littlefield/Lexington Books.

Montgomery, E. (2018). They Died in Blood: Morality and Communitas in Ewe Ritual. Journal of Ritual Studies. 32(1), 25-40.

Montgomery, E. J. (2017). Visual "Voodoo": Photo-Voice in Togo. Visual Anthropology, 30(4), 287-309.

Montgomery, E.J. (2016). "Shamanism and Voodoo in Togo: The Life and Acts of Sofo Bisi. Shaman, 24 (1-2), 65-92.

Montgomery, E., \& Vannier, C. (2017). An ethnography of a Vodu shrine in southern Togo: of spirit, slave and sea. Leiden, NE: Brill.

Olupona, J.O.K. \& Rey, T. (Eds.) (2018). Orişà devotion as world religion: the globalization of Yorùbá religious culture. Madison, WI: University of Wisconsin Press.

Orabator, A.E. (2018). Religion and Faith in Africa: Confessions of an Animist. Maryknoll, NY: Orbis Books.

Rouch, J. (2003). Cine ethnography (Trans. S. Feld). Minneapolis, MN: University of Minnesota Press.

Rouch, J.C. (Producer), \& (Director), (1968). Jaguar [Motion Picture]. France: Films de la Pléiade.

Rouch, J.C. (Producer), \& (Director), (1955), Les Maitres Fous [Motion Picture]. France: Films de la Pléiade.

Rosenthal, J. (1998). Possession, ecstasy, and law in Ewe voodoo. Charlottesville, VA: University of Virginia Press.

Rush, D. (2013). Vodun in coastal Bénin: unfinished, open-ended, global. Nashville, TN: Vanderbilt University Press.

Sarthou, S. E. (2010). Unsilencing Défilés Daughters: Overcoming Silence in Edwidge Danticat's Breath, Eyes, Memory and Krik? Krak! The Global South, 4(2), 99-123.

Scott, J. C. (2008). Weapons of the weak: Everyday forms of peasant resistance. New Haven, CT: Yale University Press.

Shaviro, S. (2002). Capitalist monsters. Historical Materialism, 10(4), 281-290.

Soederberg, S. (2004). The politics of the new international financial architecture: Reimposing neoliberal domination in the global south. London, UK: Zed Books.

Steiger, B. (2010). Real zombies, the living dead, and creatures of the Apocalypse. Canton, MI: Visible Ink Press.

Stevens, A. M. (1995). Manje in Haitian Culture: The Symbolic Significance of Manje in Haitian Culture. Journal of Haitian Studies, 1(1), 75-88.

Taussig, M. (2018). Mimesis and Alterity: A particular history of the senses. London, UK: Routledge. 


\section{éropić}

Vannier, C., \& Montgomery, E.J. (2016). Sacred Slaves: Tchamba Vodu in Southern Togo. Journal of Africana Religions 4(1), 104-127.

Washington, T. N. (2005). Our mothers, our powers, our texts: manifestations of Aje in Africana literature. Bloomington, IN: Indiana University Press. 